\title{
AUTONOMY-DRIVEN SEGMENTATION FOR COMPETITION AMONG FINNISH UNIVERSITIES: LEADERS' PERCEPTIONS
}

\author{
Vuokko Kohtamäki \\ Tampere University, Faculty of Management and Business
}

\begin{abstract}
The Finnish financial autonomy reform pushed university leaders and academics to a juncture where they must navigate through increasing competition dynamics. Enabling the two types of organisational players - foundation-run universities and universities under public law - to become more autonomous and competitive was the major element of autonomy reform. Leaders were interviewed in both types of universities to shed light on their motives for financial autonomy and strategies for dealing with simultaneous resource dependence. From the leaders' perspective, their motivations for financial autonomy were legitimised player status, power and financial benefits. The findings suggest that the two categories of players feed unprecedented horizontal segmentation for competition among Finnish universities. Foundation universities apply prestige-maximising strategies, while public universities aim to guarantee their status as regional or national education and research producers on which society depends. The most recent adaptive strategy is an institutional merger between both types of universities.
\end{abstract}

\section{Keywords}

autonomy, competition, leader, resource dependence theory, ecology of games

\section{Introduction}

This article explores Finnish universities as autonomous players in a competition-driven and globally influenced governance environment. Previously considered as state agencies, Finnish universities became independent entities, both financially and legally ${ }^{1}$ (Amaral, Tavares, and Santos 2013; Universities Act 2009). The key change allowed operating a university either as a foundation-run university or a university under public law.

Autonomy reforms in the public sector emphasise the benefits of autonomy as positive consequences in the form of superior performance following agentification, autonomisation and new executive leader roles (e.g., Verhoest et al. 2004). Financial autonomy in Western European countries, such as Finland, is provided to universities as given autonomy through a system-level reform. In new public management-oriented governance reforms, financial autonomy is granted to university-level managers to incentivise universities to respond to

\footnotetext{
${ }^{1}$ Organisationally, a university under public law is a public-sector entity but financially and legally independent. In contrast, a foundation-run university is a private-sector organisation but also financially and legally independent. Foundation universities operate under the Foundation Act and the Universities Act. Public universities operate under the Universities Act.
} 
changing competitive environments (Bleiklie, Enders, and Lepori 2017; Dobbins, Knill, and Vögtle 2011; Kwiek 2012; cf. Verhoest et al. 2004). This autonomy requires universities to become more strategic, better managed, financially entrepreneurial, and educationally productive and innovative (Keller 2007; Kwiek 2012). Four financial autonomy-related dynamics are noteworthy here.

First, financial autonomy is a multiform amoeba emerging from de jure and de facto meanings and interpretations. Financial autonomy is actively (re)designed and (re)interpreted in the prevailing competition and financial dependence-driven environments. Second, formally given spheres of autonomy (freedom or authority to make decision) and real financial autonomy (actualised element(s) or elements possible to actualise) are not necessarily identical (e.g., Christensen 2011; Kohtamäki 2011). Changes in the structures of the competitive resource environment and in the availability of resources influence how financial autonomy is realised (e.g., Cruz-Castro and Sanz-Menéndez 2018). Third, while autonomy is an important and sensitive issue for universities (e.g., Christopher 2012; Hicks 2012), its elements take shape in power-based relationships, as assumed from the new public management perspective. University leaders and managers are the ones who aspire to manage how institutional financial autonomy frames and shapes the institutions' academic and administrative operations. Public universities usually lack well-established practices for operating under the new dynamics of financial autonomy (Herbst 2007). This third type of dynamics applies specifically in country contexts where universities have the history, culture and tradition of state agencies (Amaral, Tavares, and Santos 2013; Keller 2007). Fourth, while universities have been formally given new financial autonomy frames, they are usually simultaneously dependent on state funding (Claeys-Kulik and Estermann 2015; Santiago and Carvalho 2008). Dependency cannot be entirely abolished (Goedegebuure and Meek 1994). The state governance systems' politicaladministrative traditions and history, among other things, affect and shape the universities' internal governance and management (Bleiklie, Enders, and Lepori 2017; Clark 2004).

In previous studies, a higher education institution's financial autonomy has typically been a money metric, measuring the freedom to internally allocate public funds (e.g., Christensen 2011; Pruvot and Estermann 2017; Verhoest et al. 2004). Reports on measuring and comparing the levels of formal financial autonomy of higher education systems in European countries (see, e.g., autonomy rankings by Pruvot and Extermann 2017) have recently been published. Increasing tensions between autonomy and control due to performance-based funding or other state steering mechanisms have been considered in the literature (e.g., Bleiklie, Enders, and Lepori 2017; Christensen 2011; Hicks 2012; Shattock 2014). Governmental steering has not vanished although governments have granted autonomy (e.g., Bleiklie, Enders, and Lepori 2017). Various previous studies also indicate that most European higher education institutions depend on government funding (e.g. Christensen 2011; Santiago and Carvalho 2008). Dependence restricts financial autonomy (Christensen 2011; Fowles 2014; Slaughter and Leslie 1997; Szwebs 2016). Restrictions are not the only consequences of resource dependence. Slaughter and Leslie (1997; see also Jaeger and Thornton 2005; Slaughter and Rhoades 2004) indicate the remarkable effects on external resource dependence within academia as changing the behaviour of academics. Various studies have considered changing governance from the academics' perspective (e.g., Bleiklie, Enders, and Lepori 2015; Bleiklie and Kogan 2007).

While autonomy has attracted researchers' attention for several decades, there is little research that reveals university leaders' motivations for financial autonomy and their master ideas for 
dealing with simultaneous external resource dependence. This area of research is specifically interesting in the Finnish context due to the two types of legal players that have been operated since 2009. This article's purpose is to explore the current autonomy and competition dynamics characterising Finnish universities. Two research questions guide this article, as follows: 1) What motivates university leaders to gain institutional financial autonomy in public and foundation universities? 2) How do these leaders deal with simultaneous resource dependence?

The top management perspective has been studied because financial autonomy reform is intended to serve as an institutional-level reform, with related effects (see, e.g., Ministry of Education and Culture 2016, 2017; Universities Act 2009; cf. Amaral, Tavares, and Santos 2013). At this level, leaders and managers have a university-wide management perspective on both financial autonomy and resource dependence. Since competition affects the unit level in the organisational hierarchy, academic mid-level leaders' perspectives have also been investigated. This article generates insights in the university context and demonstrates the usefulness of combining the ecology of games framework metaphor (EGF; Firestone 1989; Lubell 2013; Nisar 2015) and the resource-dependence theory (RDT; Pfeffer and Salancik 2003) in exploring the university leaders' perceptions (see the Theoretical approach section for a detailed discussion about the EGF metaphor and the RDT). This study is useful in offering reflections for university leaders, researchers and policymakers and for other countries when designing or evaluating system-level autonomy policy reforms.

This article is structured as follows: the next section outlines the Finnish universities' funding and level of financial autonomy. The third section (Theoretical approach) explains how the RDT and the EGF are applied in this study. The fourth section (Data and analysis) presents the empirical material and clarifies how it is analysed. The fifth section (Findings) discusses the findings. The final section (Conclusion) presents this study's conclusions and limitations and identifies ideas for further research.

\section{Finnish universities' revenues and level of financial autonomy}

In Finland, one of the most important governance dynamics affecting academia is the performance-based governmental block funding. All Finnish universities - public and foundation universities - are state funded and have the same public mission. Tuition fees do not comprise an institutional revenue source on which universities can rely because domestic and European Union students are not charged tuition fees. Heavily dependent on state funding (Seuri and Vartiainen 2018), Finnish universities receive it for education and research purposes based on their average education and research performance for the past three years. Their performance-based funding is one of the most competitive internationally (Seuri and Vartiainen 2018). Universities do not have shares of either historical or institutional size-based allocations.

On average, $65 \%$ of the universities' income structures comprises core governmental funding (Vipunen 2019). This figure varies among universities, depending on their success in gaining external funding for research, for example. The smallest university's (the University of Arts) share of core funding is over $90 \%$. A small multidisciplinary university receives the lowest share $(54 \%)$. The cumulative effects of external funding are well-known in university settings (see, e.g., Vieira and Lepori 2016), meaning that those with significant external funding will receive it more. 
Jointly considering the above-mentioned policy arenas, Finnish universities operate under the tension between their new financial autonomy and financial dependence (cf. Christensen 2011), as well as under the influence of political-administrative steering, channelled through competitive performance-based funding incentives, for example.

The core funding is allocated to universities as block grants. Universities have financial autonomy concerning this fund category; accordingly, they can make resource allocation decisions internally, without external constraints. The amount of governmental core funding is determined and allocated to universities using a performance-based formula, over $70 \%$ of which is based on the universities' real performance and results (Ministry of Education and Culture 2018).

The second funding stream is external funding. An emphasis on the diverse bases of operating funds has become important for interpreting the characteristics of financial autonomy (e.g., Herbst 2007; Shattock 2014; Szwebs 2016). However, institutional financial autonomy is limited in terms of external research funding. The purpose of this type of funding is increasingly defined by external funding bodies. A significant percentage of the external research funding in Finland is the governmental budget-based funding through the Academy of Finland and Business Finland (previously Tekes). In all universities, the average share of external research funding was $27 \%$ in 2018 (23\% in 2017). In this competition-based funding, funding decisions (allocations) are based on the scientific quality of research plans and funding applications. Financial cuts in public funding have led to a situation where universities must find additional funds to cover the reduced public funding (Clark 2004; Muscio, Quaglione, and Vallanti 2013). Due to decreasing public funding and the frozen core funding index, Finnish universities have cut their administrative personnel by 14\% from 2014 to 2017 (Vipunen 2019).

Universities have been entitled to undertake fundraising and financial and investment operations as part of the university autonomy reform. The state incentivised universities to carry out fundraising campaigns in 2008-2012 and 2014-2017. These were the ways to raise financial capitals for universities and strengthen their financial status. Universities were required to invest the additional state funds in their basic capital. Overall, universities' fundraising campaigns have been successful. As a result, the Finnish universities' financial status has been excellent when measured as a quick ratio (1.5) and an equity ratio (60\%; State Audit Office 2018).

Figure 1 reveals the two main categories of university revenues, as follows: 1) core funding and 2) external research funding in the 2013-2018 post-reform period. Two new categories fundraising from donors and financial investments - are post-reform revenue items of universities. The share of core funding was $51-86 \%$ of total funding, while that of external funding was $2-31 \%$ in 2017 (Vipunen 2019).

Figure 1. Revenue trends of universities, 2013-2018 (in euros) 
The European University Association has launched autonomy rankings, of which financial autonomy is one dimension (for more details, see Pruvot and Extermann 2017). Finnish universities have high-level financial autonomy in several aspects. Based on their legal status, public and foundation universities can borrow money, establish companies and take loans without restrictions. They can keep and use financial surpluses and have block-grant state funding. Restrictions apply to selling university buildings and charging tuition fees for domestic students. The level of financial autonomy in the form of metrics indicates the amount of formally available autonomy but not whether it is used, how and why.

\section{Theoretical approach}

This study integrates two theoretical approaches to explore financial autonomy and financial dependence-driven governance realities, as perceived by university leaders. Universities' dependence on governmental funding is evident in Finland. Following the definition of Verhoest et al. (2004, 106; see also De Boer and Enders 2017), 'financial autonomy refers to the extent to which the agency depends on governmental funding or own revenues for its financial resources and the extent to which it is responsible for its own losses'. Dependence and autonomy stimulate organisational actions, as assumed in the RDT (Pfeffer and Salancik 2003). The RDT focuses on top-level managers' actions and interests. As discussed by Firestone (1989) and Lubell (2013; see also Berardo and Lubell 2019), the EGF metaphor serves as a lens to explore financial autonomy and financial dependence as university games. Both theoretical approaches offer insights into motivations for financial autonomy (gains) and strategies related to resource dependence (potential loss of autonomy).

The RDT fits this study's approach since the Finnish universities' financial dependence is based on a single major funding body. However, they do not have identical levels of autonomy or dependency. Universities have different profiles, agendas and ideals as internal governance frames (Nisar 2015). The EGF aims to solve multiple collective action problems (Lubell 2013). One such issue is access to financial resources. The research questions and the country under study serve as guides to limit this article's perspective to financial resources. Pfeffer and Salancik (2003) discuss the value of key resources more broadly, covering more than financial resources. Human, political, technical and various social resources and social networks are recognised in the RDT.

In the case of resource dependence, organisational strategies and interests are shaped by the availability of critical external resources. Organisations must guarantee their incoming resources, growth and survival (Pfeffer and Salancik 2003; see also, e.g., Fowles 2014; Hillman, Cannella, and Paetzold 2000; Powell and Powell Rey 2015). In doing so, they simultaneously aspire to retain their autonomy and avoid external control and restrictions accompanying external resources. Davis and Cobb $(2009,6)$ summarise the RDT core from the top managers' viewpoint: 'Choose the least-constraining device to govern relations with your exchange partners that will allow you to minimize uncertainty and dependence and maximize your autonomy'. The EGF pays attention to multiple players and games being held concurrently. Players' strategies and decisions that aim to solve different issues evolve from various games' payoffs (Lubell 2013; Nisar 2015). Thus, decisions concerning one issue 
influence other issues directly or indirectly. The RDT does not recognise interconnections between different organisational actions.

The RDT not only focuses on the external resource environment but also reveals how the environment affects an organisation's internal dynamics. Managers can choose adaptive, discretionary and symbolic actions. The first two are intentional tactics to attain gains and avoid losses in terms of resource uncertainty and dependence. In a symbolic orientation, top managers bear their organisations' success or failure but without connections; what they do as managers does not matter (Pfeffer and Salancik 2003). The universities' financial dependence-related strategies depend on what top managers perceive and desire to achieve as outcomes, as well as what risks they are willing to take or avoid (cf. Fowles 2014; Pfeffer and Salancik 2003). Similarly, in the EGF frame, players rely on different decision heuristics in dynamic and uncertain environments (Lubell 2013).

The EGF is applied here as a metaphor that goes beyond single games. Citing Long (1958), Nisar (2015) states that games provide interaction among players by establishing a set of rules. 'Each game is a structured competition with its own rules' (Firestone 1989, 18), indicating that different games have different rules. Rules can be interpreted here as formal and informal governance policies and principles directing or guiding university players' behaviour. According to Lubell (2013) games are arenas where players cooperate, compete and learn, subject to institutional rules and the players' own goals and assumptions.

Most players prefer a single game, which is also the main determinant of their behaviour. Typically, the behaviour in one game has externalities or spillover effects on another game. (Lubell 2013; Nisar 2015.) Games are loosely connected but may influence one another, as mentioned earlier. This creates a fragmented governance context since interaction occurs mostly within a game, not among games (Firestone 1989). According to Long $(1958,252)$, 'games provide the players with a set of goals that give them a sense of success or failure'. However, the same goal has different meanings for the same players in different games (Firestone 1989).

This study approaches financial autonomy as an internal university game by asking what motivates university leaders in the context of financial autonomy. Similarly, the study considers resource dependence as a game among universities by asking how leaders and managers deal with it.

\section{Data and analysis}

This is an explorative study on post-reform financial autonomy and resource dependence from the perspective of Finnish university leaders working in public universities (12 at the time of writing this article) and foundation universities (2). Explorative research approaches typically use interviews (e.g., Stebbins 2011). Using existing interview data, this study involves 24 leaders and managers working in 14 Finnish universities. This study also uses the available national financial statistical data on Finnish universities (Vipunen 2019).

The interviewed group includes 1 chancellor, 11 rectors and vice-rectors and 5 administrative/financial directors at the university level and 7 deans at the unit level. Thus, both academic and administrative organisational leaders' and unit-level academic leaders' 
perceptions were studied. The in-text citations refer to university-level leaders with the code UL and to operational unit-level leaders with the code OL. The word 'Foundation' is added in the case of foundation universities. The interviews are analysed using theory-driven content analysis. The RDT and its assumptions, along with the game metaphor, provide the frame for empirical analysis.

\section{Findings}

\section{Motives for institutional financial autonomy}

Financial autonomy and legal status thereby engendered increasing pressure to compete and the motivation to survive. The competitive pressure was reinforced when the leaders compared the development of their respective universities to that of 'the most dynamic European universities' (OL).

Legitimised player status and new internal power relations. The ending of the era of the state agency and becoming 'full players' (OL) with financial powers and responsibilities meant that leaders perceived themselves as financial autonomy-framed agents. The universities' new legal status and its related features generated empowerment, ownership and feelings of competence at the university level. The universities' independent legal status provided their leaders with a sense of self-direction (cf. Pfeffer and Salancik 2003), as well as new circumstances with a set of changed rules and structures (cf. Nisar 2015). Independent institutional budgets, budget power and budget responsibility guaranteed power as a concrete sign of financial autonomy (cf. Pfeffer and Salancik 2003). Earlier, financial management was symbolic. It was 'like a fake economy' (UL), and the main motivation was the total amount of available funding that could be used during the financial year.

The new status enabled the availability of and access to two new financial sources (donations and incomes from financial investments) and thereby to new resource games. The legal status and new resource streams were incentivising factors when extending university leaders' interaction with external resource environment (cf. Pfeffer and Salancik 2003).

'In fundraising and communication with potential partners, being separate from the state...mentally [allows] different types of conversations. It is easier to submit a donation and fundraising requests based on an independent legal status' (UL).

New resource streams following from the legal status were also acknowledged at the unit level. '[Our university's independent legal status] enables financial investment activities; it has been very successful in our university. The returns have been positive' (OL).

The independent employer status based on the new legal status ended the civil servant employment system for the university staff and created a flexible game platform between the university and the staff to respond to the environment.

'It is in everyone's interest to get rid of civil servant employment. Gives you more flexibility to look at each of your tasks and gives you a more dynamic grip. Cooperation negotiations have taken place. Sure, pretty much has changed quite a lot in many ways. On the other hand, we needed new elements to employ and recruit people. The procedure was very cumbersome compared to the model we have now. When it comes to recruiting, there are more degrees of 
freedom compared with the civil servant system. It meets better the current times and needs. Recruiting both students and staff is important; they are millions of investments' (UL).

Control over one's actions and benefits. The feeling of control over one's actions and the concrete benefits of financial autonomy game motivated the leaders (cf. Pfeffer and Salancik 2003).

'External money has been received much more than before' (UL).

'Our economy is in tip-top condition' (UL).

'Financial independence is visible, and we have aspired to use it to [its] full potential' (UL, Foundation).

For example, the concrete benefits emerged as progress in new resource acquisitions, new internal resource allocations and extensions in external cooperation. Active fundraising accumulated to the amount of the universities' own capital, whose returns constituted a new income stream. Incomes from new financial investments enabled improvements to research infrastructures, such as facilities, equipment and services. The leaders succeeded in engaging new donors in the universities' operations and future. Additional gains from cooperating with donors were research projects with those donors working in business and industry. The Ministry of Education and Culture provided extra incentives (additional funding) for privatesector fundraising. Therefore, universities were motivated to launch specific fundraising campaigns.

Lastly, the leaders had expectations to maximise the benefits from the autonomy game. This was based on the following perceptions: 'Many opportunities are still unused' (UL). 'We must try to use new freedoms as much as possible' (OL). Future expectations concerned positive financial autonomy-related circles. Positive circles included stages, ranging from financial and human inputs to positive outputs and outcomes that were attached to the universities' better competitive status and reputation.

Changes in unit-level power. The deans perceived extended financial decision-making power and freedoms to develop their activities. A leader indicated, 'The unit leader has real power when compared with [the] earlier situation' (OL). The deans were involved in the new management systems and did not perceive interventions from the upper level. The rectors' new governance role was critical to how the unit-level autonomy would be realised. An OL argued, 'The rector trusts that we can use money.' Extended financial autonomy was also linked to organisational effectiveness. 'We have an opportunity to act more agile, and administratively and economically streamline' (OL).

Prestige game and foundation status. The prestige and the flexibility of the foundation status were extra benefits when establishing cooperation with external partners. Some donors favoured foundation universities.

'We are a foundation university. The foundation capital generates annually about 10-15 million "extra money" to the university. This money is separated from the operative funding; it is allocated to strategic targets' (UL, Foundation).

Foundation universities had a specific revenue acquisition incentive. A leader said, 'We could not have the same freedoms if we would operate with the ministerial funding alone' (UL, Foundation). This viewpoint was shared at the unit level. 'In my understanding, the funding structure has been extended during the last years' (OL, Foundation). 
The leaders emphasised that the realised financial autonomy and various entrepreneurial activities resulted in benefits, such as an extended resource base. For example, one OL (Foundation) mentioned, 'Increased autonomy enables various things, new start-up companies, [a] design factory, etc.'.

One of the foundation universities was the first one to establish its tenure-track career system. The leaders perceived pioneering benefits in the competition for human resources. The tenuretrack system provided the confirmation to implement changes; as one UL (Foundation) pointed out, 'Universities can be managed, of which a new tenure-track career system [is] an example'.

\section{Coping with resource dependence}

Both legal types of universities depended on their environment for resources (cf. Jaeger and Thornton 2005; Pfeffer and Salancik 2003; Slaughter and Rhoades 2004). Coping with resource dependence was mostly adaptive, while discretionary and symbolic actions were also identified. The leaders emphasised organisational player characters, but they also identified leaders, professors and other senior academics as players.

Distinguishing universities from their rivals and specifying arenas for competition. The leaders recognised the increasing competition against other Finnish universities and other academic units, as well as among academics. The competition demanded distinguishing themselves from rivals. A unit-level leader addressed the issue: 'We are aware of our weaknesses and know the strengths of others' (OL, Foundation). The leaders specified various competitive characteristics of their universities and units, as well as identified regional, national and international arenas for competition. Each leader made efforts to distinguish one's university by referring to its size, historical positional hierarchy, academic profile, research infrastructure, rewarding systems, the share of international academic staff members, the share of external funding, international and national networks and partners, and reputation. The foundation as a player status was repeated several times. The leaders perceived the foundation status and its dynamics as central to the institutional personality.

Addressing the dependence of the environment. The leaders highlighted the universities' socioeconomic role and expressed the opinion that society, employers and the major funding body are dependent on the university and its activities. The public universities highlighted their regional and national importance as higher education producers. Being the only provider that educates the workforce in a certain field of study was identified as indicating the dependence of the environment.

To indicate the significant and specific socioeconomic position of a foundation university, a leader pointed out, 'Our university alumni account for $90 \%$ of the top-management executives of Finnish listed companies' (UL, Foundation).

Adaptive change management strategies. The leaders applied internal change management strategies to proceed more strategically in resource competition (cf. Musselin 2018). The university-level leaders recognised the need to learn and understand the dynamics of the university as both a financially dependent and an independent player. Due to its history as a state agency, the strategies to change the internal culture of the entire university were perceived as important. The new organisational and management structures were strategies to put financial and academic performance under the universities' control (cf. Pfeffer and Salancik 2003). 
A foundation university leader highlighted changes in the university game: 'Now we operate like companies [flexible recruitments from the private sector, lay-offs, budgeting]'. To promote rapid changes and competitiveness, a coalition-type relationship between the top foundation university leaders and the university's board members was perceived (cf. Pfeffer and Salancik 2003). With the support of the external university board members, a clear division between strategic and operative management was made to improve the ability to change and compete ${ }^{2}$. 'External board members are academically merited and represent the very top of business people. They give support and encourage us to renew' (OL, Foundation).

The leaders emphasised the partners and the human resources available in the external environment. As the RDT points out, managers try to 'direct organization[s] toward more favourable environments' (Pfeffer and Salancik 2003, 263). Three discretionary human resource-related strategies can be perceived. As the first strategy, fixed-term work contracts were applied to guarantee the flow of external funding. According to one dean, 'External funding and fixed working contracts of researchers are connected' (UL). This was legitimised by a university-level leader in this way, 'There have always been temporary working contracts'. The second strategy involved new staff recruitments [administrators and academics] from the private sector to change the old state-agency culture. The leaders preferred to hire new people outside the university because 'they have a totally different way of thinking' (UL). The fast governance changes also raised concerns. 'You have to be careful that efficiency does not drive over academic functions. That a controller does not define what a department can do' (UL, foundation). A foundation university highlighted open international recruitments to attract academic talents. In a foundation university, one-third of its academic staff members came from other countries, bringing new networks to the university. As the third strategy, tenuretrack career systems were applied in public and foundation universities to compete for academic staff. In a foundation university, the tenure-track career system and international recruitments led to successful results when competing for external funding. The same university applied its own salary system, increasing its competitiveness.

Competing for resources. Being engaged in gaming to maximise the possibilities to win external research funding and obtaining funding from donors were prioritised as financial strategies. One of the foundation universities had the largest share of external research funding (37\%), while the average share of all universities was 27\% (Vipunen 2018). In absolute numbers, the same foundation university has been the most successful in its fundraising campaigns. The leaders put their efforts in professional fundraising, fundraising campaigns and making fundraising a continuous, full-time activity. Highlighting the foundation's prestige was both a discretionary and a symbolic strategy to keep the foundation image known among potential donors and partners. The importance of sub-units and unit-level leaders was identified (cf. Pfeffer and Salancik 2003). Accordingly, university-level leaders delegated critical responsibilities - to compete for both funding and academic reputation - to academic mid-level leaders.

Units as players. The units were active players. 'Times have changed; we operate like any other company' (OL). The same leader continued, 'It is the money that guides our operations'. The leaders perceived the critical dependence on individual academics and their capacity and orientation to apply for external funding. At a foundation university, the professors' role was

\footnotetext{
${ }^{2}$ One main internal governance difference between public and foundation universities is the composition of the university governing board. If foundation universities prefer, they can have external board members only, but public universities are required to limit the number of external board members to $40 \%$ of the membership (Universities Act 2009).
} 
regarded as a 'top job' (OL) that was exempted when cutting the number of personnel. The unit-level leaders also demonstrated their recognition of the institutional level. Profiling of research and financial inputs as core areas comprised both institutional and unit-level responses to competitive resource games. Teaching 'the logic [of] how we get money is something we keep in our hands' (OL). The units enhanced engagements in gaming by using research sabbaticals, administrative support for research applications, grant-writing support, sparring and so on. In a foundation university, the transition to a business orientation and risk taking were perceived. A unit-level leader pointed out, 'keeping business running with partners from industry... $70 \%$ of our funding is unstable (industry, Business Finland, Ministry of Education and Culture)'. A leader continued, 'In practice, we sell projects to the industry. It is the full business; $40 \%$ of our projects are real business. We have to take care of our business side' (OL, Foundation). At the unit level, running the core operations required paying attention to both teaching and research. Operating as part of a large well-known university was identified as a condition for survival. The tendency of teaching and research to diverge was a perceived challenge. In international recruitments, reputation based on research and personal research networks were prioritised, but these had consequences for teaching. Foreign professors also had to teach, but the (Finnish) language issue was problematic. The units cannot recruit teaching-only personnel because 'you do not know what to teach if you do not research. It is dangerous if they [research and teaching] diverge' (OL, Foundation).

\section{Conclusion}

Competition and change pressures are not novelties in universities; they have characterised higher education environments for over two decades. After relinquishing its state-agency status, the academic enterprise is now faced with increasing complexity, which also concerns Finnish higher education institutions (cf. Amaral, Tavares, and Santos 2013; Clark 2004; Keller 2007; Kwiek 2012). Universities are (in)dependent, financial autonomy-framed agents; this status offers and requires a new, demanding competitive player role for leaders and managers (cf. Keller 2007; Musselin 2018).

The perceived motives behind financial autonomy and the strategies to deal with resource dependence shed light on them as games played by universities. The components flowing to these games arrive from various sources (Firestone 1989; Lubell 2013). Simultaneous financial autonomy and resource dependence and their evolution are driven by the results of the interaction among several components (players, issues, interests), as assumed in the EGF metaphor and the RDT. This study indicates that university leaders are active players (cf. Lubell 2013; Nisar 2015; Pfeffer and Salancik 2003). They are not identical players, nor are games identical across universities. Players' cognitive dispositions, motives, heuristic devices and experiences are the driving forces of the interaction in the EGF (cf. Lubell 2013).

Status, power, prestige and financial benefits, as part of financial autonomy game, motivate university leaders. Financial autonomy game and players' interests shed light on internal power games and prestige games. Players identify the gains from these games as providing legitimacy, better visibility to external partners (cf. Pfeffer and Salancik 2003; Powell and Powell Ray 2015) and access to two new resource items - gifts and investments. Universities become dependent on various internal games played in the context of financial autonomy (cf. Nisar 2015). From the dependence follows that universities are willing to change their behaviour 
according to potential gains or losses in different games (Nisar 2015). Such gains or losses are direct or indirect externalities affecting other games (Lubell 2013). Simultaneous multiple and interlinked games generate complexity (Berardo and Lubell 2019). Therefore, the patterns and levels of interconnections or discontinuities among various games are not always predictable or perceivable by players (Firestone 1989; Nisar 2015).

Resource dependence as such does not determine behaviour but influences available strategies, from which players choose the most appropriate one (Crozier and Friedberg 1980). To deal with resource dependence, universities play human resource and change management games and various other related games. A primary visible financial resource game is a performancebased funding game among universities, where the players either win or lose (cf. Firestone 1989; Nisar 2015; Seuri and Vartiainen 2018). Performance-based funding games are platforms that have increased universities' dependence on individual academics and the state (e.g., Musselin 2018). The universities' reputation and status attached to external research funding are examples of direct positive externalities of funding games (cf. Kwiek 2012; Lubell 2013; Marginson 2004; Musselin 2018).

Legal status is a new game in the ecology of games among universities. The legal status game dynamic seemed to engender a new horizontal segmentation between public and foundation universities based on their perceived strategies for dealing with resource dependence (cf. Musselin 2018). Foundation universities were found to be foundation-prestige maximisers. Strong internationalisation, entrepreneurial orientation and the strategy to use foundation prestige to its full potential were identified. Cooperation with external partners was intensive, and some donors preferred foundation-run universities. While the foundation leaders emphasised rapid internal governance changes, the public universities illustrated adaptive strategies to learn entrepreneurial actions and the characters of independent financial players. Public universities focused on their national and/or regional higher education roles but also indicated actions to distinguish themselves (and their reputation) from their rivals. The university organisation itself with new strategic attempts comprised adaptive and discretionary responses to the environment (cf. Jaeger and Thornton 2005; Pfeffer and Salancik 2003) by both types of universities but with varying intensities, feeding the differences between them.

Beyond the interviews, the most recent competition-driven adaptive game strategy in the Finnish higher education context is an institutional merger between a public and a foundation university in 2019. Its new legal status is based on the foundation law (Myklebust 2019). A competitive segmentation has emerged as a move from a public university category to the group of foundation universities. A new foundation university is the second largest in student numbers and the third largest in the absolute volume of both governmental core funding and external research funding. The merger can be perceived as a reaction to current changes threatening the institutional position to win resources (cf. Goedegebuure and Meek 1994).

The inner structure of university games has changed as part of the ecology of resource dependence and financial autonomy games. The changes of the games are not necessarily equitable or fair for all players (Lubell 2013). Contradictions occur between players due to different interests and playing strategies. All players cannot play according to their strategies (cf. Crozier and Friedberg 1980). Finnish universities have adopted such internal power games that affect academic games (cf. Locke and Bennion 2013). Key academic functions (research, teaching and third-mission services) are games of their own and academics have rules in their 
games (Firestone 1989). The science institution and knowledge flow in the scientific system are subject to "shifting fortunes" and "attacks" Merton ([1942] 1973, 267). In the EGF games create new games and new collective action problems to solve (cf. Lubell 2013), as "no single actor or set of actors sees the whole picture" (Lubell 2013, 545). Despite the intended autonomy policy reform multiple games emerge organically without the central control from the top level of an organisation or of external steering (cf. Nisar 2015).

Financial autonomy and financial resource games are structurally and operationally more extensive than this study's scope, which covers only a few of their key aspects. Games change over time, and different policy issues involve various players. Players' strategies and perceived losses and gains do not reveal all aspects of the games. Players' choices can modify the game itself. Players are not necessarily rational in making choices; they have different experiences, are surrounded by various indirect constraints and can change their course of action during games (cf. Crozier and Friedberg 1980). As a result, the changing landscape of financial autonomy and resource dependence has only been partially analysed. Further qualitative studies are needed to analyse various modes of financial resource-driven game realities in the context of state revenues and project-funded operations. The consequences of competition call for further research, specifically how this type of research environment influences individual academics and their careers.

\section{References}

Amaral, A., O. Tavares, and C. Santos. 2013. "Higher Education Reform in Portugal: A Historical and Comparative Perspective of the New Legal Framework for Public Universities." Higher Education Policy 26 (1): 5-24.

Berardo, R., and Lubell, M. 2019. "The Ecology of Games as a Theory of Polycentricity: Recent Advances and Future Challenges.” Policy Studies Journal 47(1): 6-26.

Bleiklie, I., J. Enders, and B. Lepori. 2015. "Organizations as Penetrated Hierarchies: Environmental Pressures and Control in Professional Organizations." Organization Studies 36 (7): 873-896.

Bleiklie, I., J. Enders, and B. Lepori. 2017. Managing Universities: Policy and Organizational Change from a Western European Comparative Perspective. New York: Palgrave Macmillan.

Bleiklie, I., and M. Kogan. 2007. "Organization and Governance of Universities.” Higher Education Policy 20 (4): 477-493.

Christensen, T. 2011. "University Governance Reforms: Potential Problems of More Autonomy?" Higher Education 62 (4): 503-517.

Christopher, J. 2012. "Governance Paradigms of Public Universities: An International Comparative Study." Tertiary Education and Management 18 (4): 335-351.

Claeys-Kulik, A.-L., and T. Estermann. 2015. Define Thematic Report: Performance-Based Funding of Universities in Europe. Brussels: European University Association. 
Clark, B. R. 2004. "Delineating the Character of the Entrepreneurial University." Higher Education Policy 17 (4): 355-370.

Crozier, M. and Friedberg, E. 1980. Actors and systems: The politics of collective action. Chicago and London: University of Chicago Press.

Cruz-Castro, L., and Sanz-Menéndez, L. 2018. "Autonomy and Authority in Public Research Organisations: Structure and Funding Factors." Minerva 56 (2): 135-160.

Davis, G. F., and J. A. Cobb. 2009. "Resource Dependence Theory: Past and Future." Research in the Sociology of Organizations 1970-2000 28: 21-42.

De Boer, H., and J. Enders. 2017. "Working in the Shadow of Hierarchy: Organisational Autonomy and Venues of External Influence in European Universities." In Managing Universities: Policy and Organizational Change from a Western European Comparative Perspective, edited by I. Bleiklie, J. Enders, and B. Lepori, 57-83. New York: Palgrave Macmillan.

Dobbins, M., C. Knill, and E. M. Vögtle. 2011. "An Analytical Framework for the CrossCountry Comparison of Higher Education Governance." Higher Education 62 (5): 665-683.

Firestone, W. A. 1989. "Educational Policy as an Ecology of Games.” Educational Researcher 18 (7): 18-24.

Fowles, J. 2014. "Funding and Focus: Resource Dependence in Public Higher Education." Research in Higher Education 55 (3): 272-287.

Goedegebuure, L. C. J., and V. L. Meek. 1994. "A resource dependence perspective on mergers. Comparing institutional amalgamations in Australia and the Netherlands." In Comparative Policy Studies in Higher Education, edited by Goedegebuure, LCJ and FA van Vught,127-164. Utrecht: Lemma.

Herbst, M. 2007. Financing Public Universities: The Case of Performance Funding. Dordrecht: Springer.

Hicks, D. 2012. "Performance-Based University Research Funding Systems." Research Policy 41 (2): 251-261.

Hillman, A. J., A. A. Cannella, and R. L. Paetzold. 2000. "The Resource Dependence Role of Corporate Directors: Strategic Adaptation of Board Composition in Response to Environmental Change.” Journal of Management Studies 37 (2): 235-256.

Jaeger, A. J., and C. H. Thornton. 2005. "Moving Toward the Market and Away from Public Service? Effects of Resource Dependency and Academic Capitalism." Journal of Higher Education Outreach and Engagement 10 (3): 53-67.

Keller, G. 2007. "Higher Education Management: Challenges and Strategies." In International Handbook of Higher Education, edited by J. J. F. Forest and P. G. Altbach, 229-242. Dordrecht: Springer.

Kohtamäki V. 2011. "How do Higher Education Institutions enhance their Financial Autonomy? Examples from Finnish Polytechnics.” Higher Education Quarterly 65 (2), 164185.

Kwiek, M. 2012. "The growing complexity of the academic enterprise in Europe: A panoramic view." European Journal of Higher Education 2(2-3): 112-131. 
Locke, William, and Alice Bennion. "Satisfaction in stages: The academic profession in the United Kingdom and the British commonwealth." In Job satisfaction around the academic world, pp. 223-238. Springer, Dordrecht, 2013.

Long, N. E. 1958. “The Local Community as an Ecology of Games." American Journal of Sociology 64 (3): 251-261.

Lubell, M. 2013. "Governing institutional complexity: The ecology of games framework." Policy Studies Journal 41 (3): 537-559.

Marginson, S. 2004. "National and Global Competition in Higher Education." The Australian Educational Researcher 31 (2): 1-28.

Merton, R.K. (1973) 1942. "The Normative Structure of Science'." In The Sociology of Science: Theoretical and Empirical Investigations, edited by Norman W. Storer, 267-78. Chicago: The University of Chicago Press.

Ministry of Education and Culture. 2016. Yliopistolakiuudistuksen vaikutusten arviointi. Loppuraportti 30.6.2016. Opetus- ja kulttuuriministeriön julkaisuja 2016: 30. Helsinki: Opetus- ja kulttuuriministeriö.

Ministry of Education and Culture. 2017. "Yliopistot onnistuivat varainhankinnassa—valtio pääomittaa 150 miljoonan vastinrahalla." ["Universities Succeeded in Fundraising-State Provides 150 Million Additional Funding.”] Accessed 2 June 2019.

https://minedu.fi/artikkeli/-/asset_publisher/yliopistot-onnistuivat-vastinrahakampanjassayksityista-paaomaa-keratty-130-miljoonaa-euroa

Ministry of Education and Culture. 2018. "Yliopistojen rahoitusmalli 2017 alkaen." ["Core Funding Model of Universities from 2017 Onwards.”] Accessed 2 June 2019. https://minedu.fi/documents/1410845/4392480/amk_rahoitusmalli_2017

Muscio, A., D. Quaglione, and G. Vallanti. 2013. "Does Government Funding Complement or Substitute Private Research Funding to Universities?” Research Policy 42 (1): 63-75.

Musselin, C. 2018. "New Forms of Competition in Higher Education." Socio-Economic Review 16 (3): 657-683.

Myklebust, P. 2019. "Merger Makes Tampere the Second-Largest University.” University World News. Accessed 1 June 2019.

https://www.universityworldnews.com/post.php?story=2019011013130145

Nisar, M. A. 2015. "Higher Education Governance and Performance-Based Funding as an Ecology of Games." Higher Education 69 (2): 289-302.

Pfeffer, J., and G. R. Salancik. 2003. The External Control of Organizations: A Resource Dependence Perspective. Stanford: Stanford University Press.

Powell, K. K., and M. Powell Rey. 2015. "Exploring a Resource Dependency Perspective as an Organizational Strategy for Building Resource Capacity: Implications for Public Higher Education Universities." Management in Education 29 (3): 94-99.

Pruvot, E. B., and T. Estermann. 2017. University Autonomy in Europe III: The Scorecard 2017. Accessed 1 June 2019. http://www.eua.be/Libraries/publications/UniversityAutonomy-in-Europe-2017 
Santiago, R., and T. Carvalho. 2008. "Academics in a New Work Environment: The Impact of New Public Management on Work Conditions." Higher Education Quarterly 62 (3): 204-223. doi:10.1111/j.1468-2273.2008.00390.x

Seuri, A., and H. Vartiainen. 2018. "Yliopistojen rahoitus, kannustimet ja rakennekehitys." ["Funding, Incentives and Strategic Development of Universities."]. Talouspolitiikan arviointineuvoston taustaraportti. Accessed 1 June 2019. https://www.talouspolitiikanarviointineuvosto.fi/wordpress/wpcontent/uploads/2018/01/Seuri_Vartiainen_2018-1.pdf

Shattock, M. 2014. "Autonomy, Self-Government and the Distribution of Authority." In International Trends in University Governance, edited by M. Shattock, 184-198. London: Routledge.

Slaughter, S., and L. L. Leslie. 1997. Academic Capitalism: Politics, Policies, and the Entrepreneurial University. Baltimore: Johns Hopkins University Press.

Slaughter, S., and G. Rhoades. 2004. Academic Capitalism and the New Economy: Markets, State, and Higher Education. Baltimore: Johns Hopkins University Press.

State Audit Office. 2018. Yliopistojen valtionrahoitus. [State Funding of Universities.] Tarkastuskertomus 10/2018. Helsinki: Grand Oy.

Stebbins, Robert A. (2011). Exploratory Research in the Social Sciences. Thousand Oaks: Sage.

Szwebs, W. 2016. "Institutional Financial Autonomy in Practice: A Departmental Perspective. In (Re) discovering University Autonomy, edited by R. V. Turcan, J. E. Reilly, and L. Bugaian, 107-122. New York: Palgrave Macmillan. https://doi.org/10.1057/9781137388728_8

Universities Act. 2009. Accessed 12 June 2019.

https://www.finlex.fi/en/laki/kaannokset/2009/en20090558.pdf

Verhoest, K., B. G. Peters, G. Bouckaert, and B. Verschuere. 2004. "The Study of Organisational Autonomy: A Conceptual Review." Public Administration and Development 24 (2): 101-118.

Vieira, E. S., and B. Lepori. 2016. "The Growth Process of Higher Education Institutions and Public Policies.” Journal of Informetrics 10 (1): 286-298.

Vipunen. 2019. Education Statistics Finland. Accessed 10 June 2019. https://vipunen.fi/fi-fi 